\title{
Erratum
}

\section{A network of p73, p53 and Egr1 is required for efficient apoptosis in tumor cells}

\author{
$\mathrm{J}$ Yu, V Baron, D Mercola, T Mustelin and ED Adamson \\ Cell Death and Differentiation (2007) 14, 640. doi:10.1038/sj.cdd.4402093
}

Correction to: Cell Death and Differentiation 2006; doi:10.1038/sj.cdd.4402029. Advance online publication, 22 September 2006.
The authors have identified an error in the legend for Figure 2. Please see correct figure legend below.

We would like to apologise for the error and any inconvenience this may have caused.
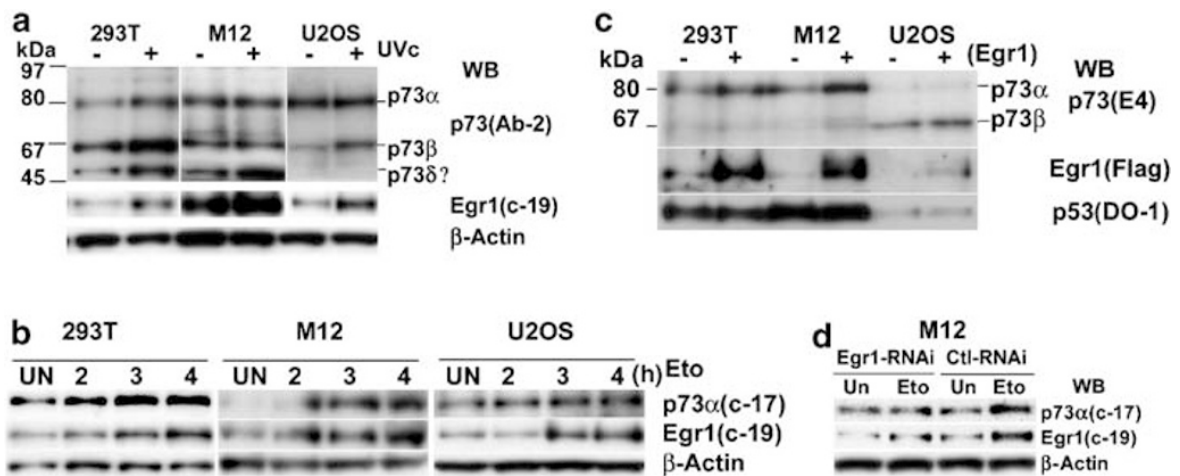

Figure 2 Immunoblots indicate that Egr1 and p73 are induced by UV irradiation or ETO treatment of a variety of cell types. (a) UVc irradiation (40 J/M ${ }^{2}$ ) of three cell types induced Egr1 and p73 protein isoforms measured $4 \mathrm{~h}$ later. (b) ETO $(20 \mu \mathrm{g} / \mathrm{ml})$ added to three cells types induced Egr1 and p73 $\alpha$ in a time-course study. (c) Transfection of an Egr1 expression plasmid into three cell lines induced $p 73 \alpha$ and $\beta$ protein isoforms. (d) Egr1 RNAi reduces the induction of Egr1 and p73 $\alpha$ in ETO treated M12 prostate cancer cells, while a control RNAi has no effect 